Eur J Clin Chem Clin Biochem

1995; 33:661-671

(c) 1995 Walter de Gruyter \& Co. Berlin · New York

\title{
Discovery and Clinical Applications of Bone Morphogenetic Proteins
}

\author{
By Slobodan Vukičević ${ }^{1}$, Ana Stavljenic ${ }^{3}$ and Marko Pećina ${ }^{2}$
}

1 Department of Anatomy, Zagreb University School of Medicine Zagreb, Croatia

2 Department of Orthopaedic Surgery, Zagreb University School of Medicine and Zagreb Clinical Hospital, Zagreb, Croatia

3 Clinical Institute of Laboratory Diagnosis, Zagreb University School of Medicine and Zagreb Clinical Hospital, Zagreb, Croatia

(Received March 9/July 25, 1995)

Summary: Significant progress has been made in the characterization of cartilage and bone differentiating proteins. A family of unique proteins known as bone morphogenetic proteins has been described, and there is ample evidence that they are directly responsible for de novo cartilage and bone formation in vivo. Extensive research is underway to develop appropriate and optimal delivery systems based on extracellular matrix components. It is likely that bone morphogenetic proteins will play a crucial role in bone and joint regeneration and repair.

\section{Epithelial and Bone Matrix Induced Osteogenesis}

The bone has a remarkable potential for repair and regeneration. Regeneration processes such as fracture repair, recapitulate events that occur in the course of embryonic bone development. Experimental means of inducing new bone formation at non-bony sites have been known for years. In early 1930, Huggins (1) discovered that surgical transplantation of living urinary bladder epithelium into abdominal muscles in dogs resulted in new bone formation. The phenomenon was termed "epithelial osteogenesis". Urist (2) and Reddi \& Huggins (3) have shown that implantation of demineralized bone matrix into intramuscular or subcutaneous sites induced a sequence of cellular events leading to the formation of cartilage, bone, and bone marrow. The events were termed "matrix-induced endochondral bone formation". Inductive properties of demineralized bone matrix implantation at heterotopic sites are also reminiscent of embryonic bone development. It is believed that the putative molecules responsible for epithelial and matrix-induced osteogenesis may have common structural properties, although this has not yet been demonstrated.

\section{Demineralized Bone Matrix-Induced Osteogenesis}

The cascade of matrix-induced endochondral bone formation consists of chemotaxis, attachment of mesenchymal stem cells to the matrix, proliferation of progenitor cells, and differentiation of cartilage (fig. 1). This is followed by cartilage resorption, bone formation, and finally culminating in the formation of an ossicle filled with haematopoietic marrow (4). On day 1 , fibronectin is deposited on the matrix facilitating cell attachment. On days 2 and 3, proliferation of mesenchymal cells takes place. This cell-matrix interaction results in the differentiation of chondroblasts at day 5 , with appearance of cartilaginous matrix as shown by an increased ${ }^{35} \mathrm{~S}$ (sulfate) incorporation into proteoglycans, and the appearance of hypertrophic chondrocytes at day 7. Angiogenesis with cartilage resorption starts on day 9 , and new bone formation in association with ${ }^{45} \mathrm{Ca}$ incorporation into new bone mineral occurs at day 11 (fig. 1). Extensive bone remodeling with haematopoietic marrow formation, as evidenced by ${ }^{59} \mathrm{Fe}$ incorporation, is maximal on day 21 . This development programme is a single cycle of cartilage and bone formation, and recapitulates the embryonic development of limbs (fig. 1). It could be 


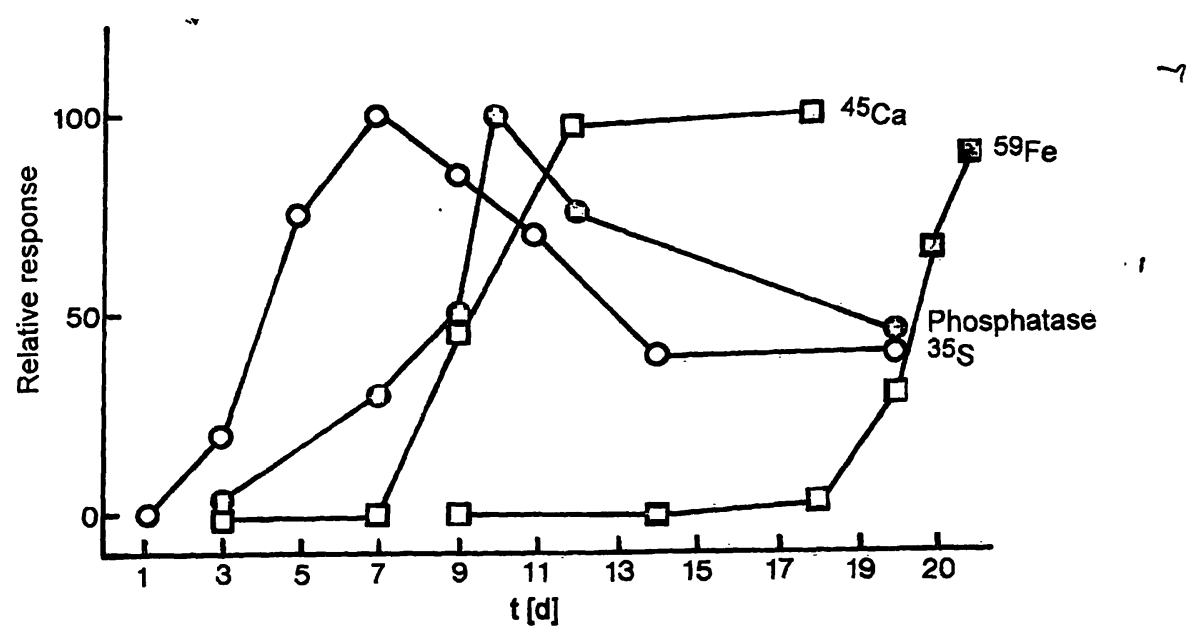

Fig. 1 Induction of endochondral bone formation cascade after subcutaneous implantation of demineralized bone matrix. ${ }^{35} \mathrm{~S}$ indicates incorporation of sulfate into proteoglycans during chondro- genesis. Phosphatase stands for alkaline phosphatase in indicating osteogenesis. ${ }^{45} \mathrm{Ca}$ reflects mineralization of bone matrix, and ${ }^{59} \mathrm{Fe}$ measures haematopoiesis. a useful model for fracture healing. Moreover, this system enables molecular studies at the different stages of endochondral bone formation and a better understanding of the role of endogenous and exogenous growth and differentiation factors involved.

\section{The Discovery of Osteogenin and other Bone Morphogenic Proteins}

Identification of osteogenic proteins in mammalian bone matrix responsible for this cascade of cartilage and bone differentiation has been a difficult task due to the low abundance of osteogenin and related bone morphogenetic proteins tightly bound to the bone extracellular matrix. Progress in recent years in the study of bone morphogenetic proteins has been aided by four important technical developments, namely:

1. the development of a functional bioassay in a subcutaneous site in a rat to monitor the specific biology of osteogenic activity $(5,6)$;

2. the development of a specific purification procedure involving heparin affinity chromatography (7);

3. the use of electroendosmotic elution techniques after preparative sodium dodecyl sulfate gel electrophoresis to achieve final purification homogeneity (8); and

4. the use of recombinant DNA methodologies for the cloning and expression of several members of the bone morphogenetic proteins family $(9-12)$.

A breakthrough in the isolation of osteogenic activity has been the dissociative extraction of demineralized bone matrix by $4 \mathrm{~mol} / \mathrm{l}$ guanidinium hydrochloride, or $8 \mathrm{~mol} / 1$ urea (5). Neither the soluble extract nor the residual bone powder alone had detectable activity when implanted subcutaneously in a rat. However, when the extract was re- constituted with the inactive residue, biological activity of bone and cartilage formation was recovered (fig. 2). This reconstitution assay has permitted the further purification of osteogenic components. Additional experiments revealed that irrespective of the species, the lower molecular weight fractions of a $4 \mathrm{~mol} / \mathrm{l}$ guanidinium hydrochloride extract following molecular sieve chromatography induced new cartilage and bone formation in rats (5). This discovery set the stage for the large scale purification of bone and cartilage inducing proteins.

A group of related bone morphogenetic factors has been discovered that include osteogenin, bone morphogenetic protein-2 (BMP-2), BMP-3, BMP-4, BMPs 5 and 6, osteogenic protein-1 (BMP-7), and osteogenic protein-2 (BMP-8) $(8-11,13,14)$. Osteogenin was purified to

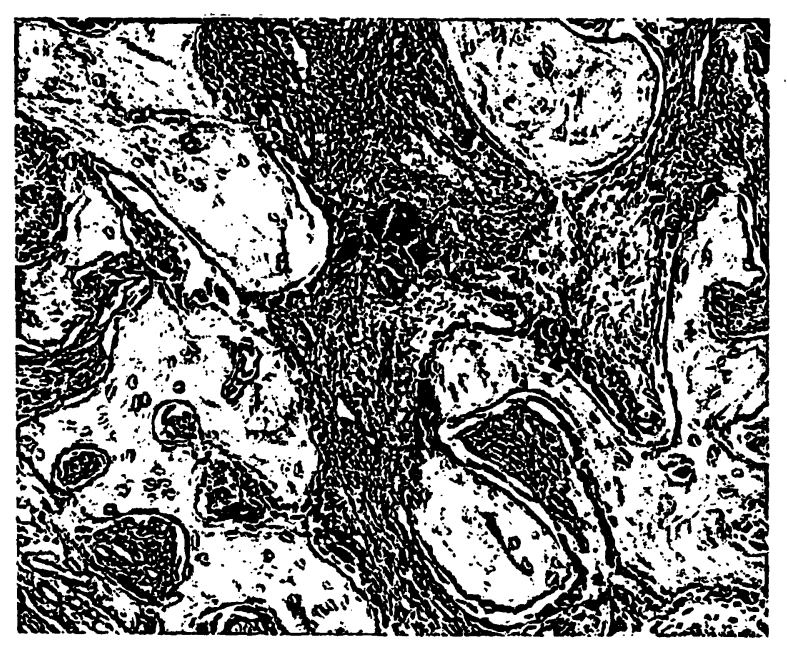

Fig. 2 Photomicrograph of a histological section of an implant of baboon insoluble collagenous matrix reconstituted with baboon osteogenin (bone morphogenetic protein-3) and implanted extraskeletally in baboons. Note bone differentiation in direct contact with the implanted collagenous matrix. Contiguous osteoblasts lining the newly formed bone (toluidine blue; $\times 125$ ) (Reproduced from Ripamonti et al.: Matrix 1992; 12:369) (44). 
Tab. 1 Family of bone morphogenetic proteins (BMPs) and cartilage-derived morphogenetic proteins (CDMPs) of the transforming growth factor- $\beta$ superfamily

\begin{tabular}{lll}
\hline BMP/CDMP & Other names & $\begin{array}{l}\text { Bone and } \\
\text { cartilage } \\
\text { induction }\end{array}$ \\
\hline BMP-2 & BMP-2A & + \\
BMP-3 & Osteogenin & + \\
BMP-4 & BMP-2B & + \\
BMP-5 & - & $?$ \\
BMP-6 & Vgr-1 & + \\
Osteogenic protein-1 & BMP-7 & + \\
Osteogenic protein-2 & BMP-8 & $?$ \\
CDMP-1 & GDF-5 & + \\
CDMP-2 & GDF-6 & $?$ \\
\hline
\end{tabular}

(a)

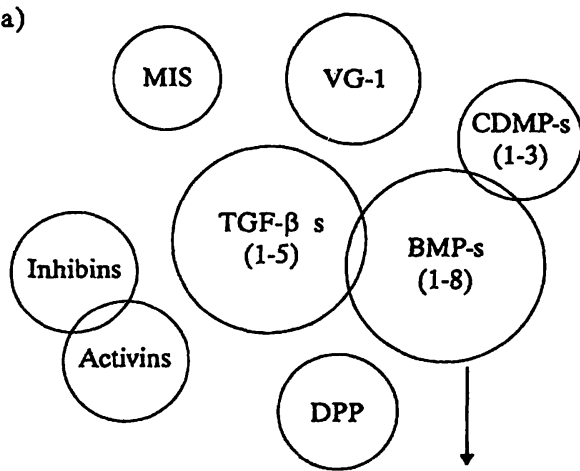

Transforming growth factor- $\beta$ (TGF- $\beta$ ) superfamily

Osteogenin / Bone morphogenetic protein family

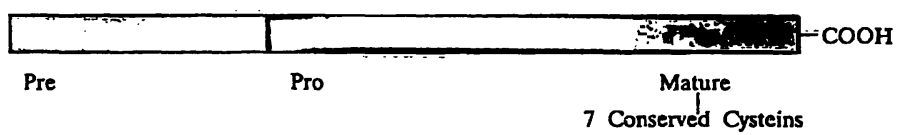

\begin{tabular}{lc} 
Family member & $\begin{array}{c}\text { Fraction } \\
\text { conserved }\end{array}$ \\
\hline Osteogenin (BMP-3) & 100 \\
Bone morphogenetic protein-2 (BMP-2) & 49 \\
Bonc morphogenetic protein-4 (BMP-4) & 48 \\
Bone morphogenetic protein-5 (BMP-5) & 37 \\
Bonc morphogenetic protein-6 (BMP-6) & 43 \\
Osteogenic protein-1 (OP-1, BMP-7) & 42 \\
Osteogenic protein-2 (OP-2, BMP-8) & 43 \\
Cartilage-derived morphogenetic protein-1 (CDMP-1) & 23 \\
Cartilagc-derived morphogenetic protein-2 (CDMP-2) & 24 \\
Cartilagc-derived morphogenetic protein-3 (CDMP-3) & 23
\end{tabular}

(b)

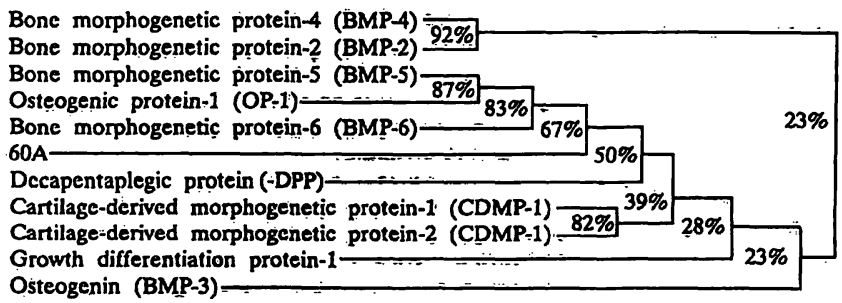

Fig. 3a Members of the transforming growth factor $\beta$ (TGF= $\beta$ ) superfamily.

DPP = decapentaplegic protein; MIS = Müllerian inhibiting substance; VG-1 = vegetal pole derived transcripts; $\mathrm{BMPs}=$ bone morphogenetic proteins; CDMPs = cartilage-derived morphogenetic proteins. Percentage identity in comparison to bone morphogenetic protein-3.

Fig. 3b Identities between 7-cysteine mature portions of the transforming growth factor $\beta$ family members. homogeneity from bovine bone matrix, and the sequences of several tryptic peptides were determined (8). The sequences were similar to portions of the amino acid sequence deduced from the cDNA clone of bone morphogenetic protein-3 (9). Osteogenin shows 49 and $48 \%$ sequence identity in its carboxyl-terminal quarter to bone morphogenetic protein-2 and bone morphogenetic protein-4, respectively (9). Bone morphogenetic protein-7 was found to be identical to osteogenic protein-1 $(11,14)$. Based on structural and amino acid sequence homologies, these osteogenic proteins are grouped among members of the transforming growth factor $\beta$ superfamily (tab. 1), all of which share a striking homology in the C-terminal domain (fig. 3a).

Osteogenin and related bone morphogenetic proteins initiate cartilage and bone formation in vivo. Bone morphogenetic protein-3 is most abundant in the highly purified preparations, but other members, especially bone morphogenetic protein-2 and bone morphogenetic protein-7 (osteogenic protein-1), are also present in the bioactive highly purified bone-derived fractions. Bone morphogenetic proteins $2-4$ and bone morphogenetic protein-7 have been reported to induce cartilage and bone as single recombinant proteins in conjunction with residue $(9,11,12,14)$. The availability of all the recombinant proteins will allow researchers to address the question of particular functions of different members in endochondral bone formation more accurately. The studies of the mechanism of action of the bone morphogenetic proteins will add considerable new information on the
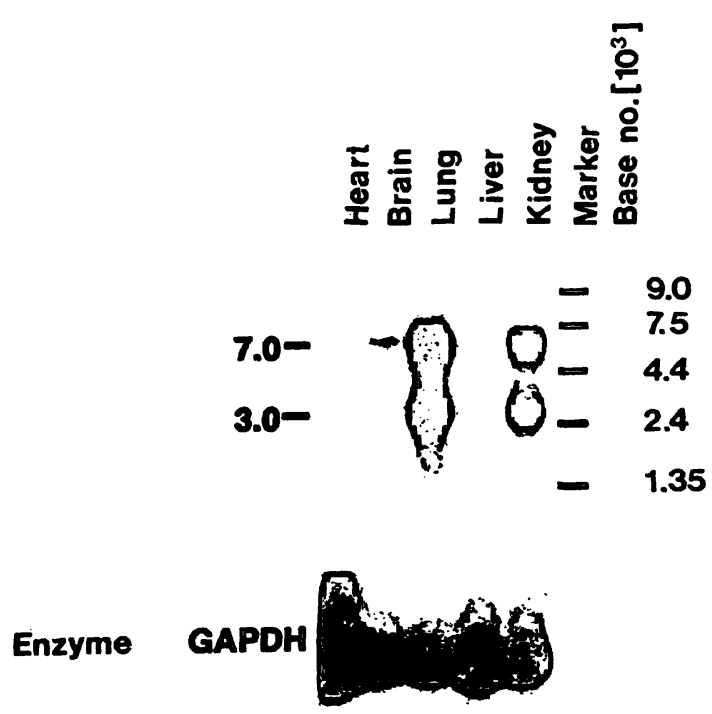

Fig. 4 mRNA expression of bone morphogenetic protein-3 in fetal human tissues. The sizes of the bone morphogenetic protein-3 mRNA species are shown on the left. Fetal (12-14 weeks) tissues are indicated above the lanes.

RNA sieve markers are indicated on the right $(9.0,7.5,4.4,2.4$ and $1.35 \cdot 10^{3}$ bases). (Enzyme = glyceraldehyde phosphate dehydrogenase.) (Reproduced from Vukičević et al.; J Histochem Cytochem $1994 ; 7: 869$ ). 
molecular signals controlling cartilage and bone formation, as well as cartilage and bone regeneration.

As in the case of transforming growth factor- $\beta$, members of transforming growth factor- $\beta$ superfamily are synthesized as a large precursor, four times greater than the mature form of the molecule. Members of this family encode secreted polypeptides that share common structural features (fig. $3 b$ ). They are proteolytically processed from the pro-protein to yield the carboxyl terminal mature proteins of approximately 110 amino acids as disulphide-linked homodimers. The active ligand form is a disulphide-bonded homodimer of a single family member or a heterodimer of two different members (15-17). All members share a conserved pattern of seven highly conserved cystein residues.

\section{Involvement of Bone Morphogenetic Proteins in Development}

There is accumulating evidence that morphogenetic proteins are important regulators of many morphogenetic events during embryogenesis. For example, recent in situ hybridization studies for bone morphogenetic protein-2, bone morphogenetic protein- 4 and bone morphogenetic protein- 6 revealed, in addition to the expected localization of transcripts in cells involved in skeletal morphogenesis, mRNA transcripts in several extraskeletal organs and tissues, namely: the developing limb, the myogenic layer of the atrioventricular cushions of the developing heart, developing hair and whisker follicles, tooth buds and palate, developing central nervous system and craniofacial tissues $(18-20)$. Osteogenic protein-1 was identified in human placenta and in brain cDNA libraries (21) and by Northern hybridization analysis bone morphogenetic protein-3 to 6 mRNAs have been found in the lung (fig. 4). Bone morphogenetic protein- 3 message was found by in situ hybridization in perichondrium, periosteum/osteoblast layer, intestine, kidney and lung, which is a major site of synthesis during development $(21,22)$.

By using Northern analysis and immunohistochemistry, osteogenic protein-1 was localized not only in osteo-
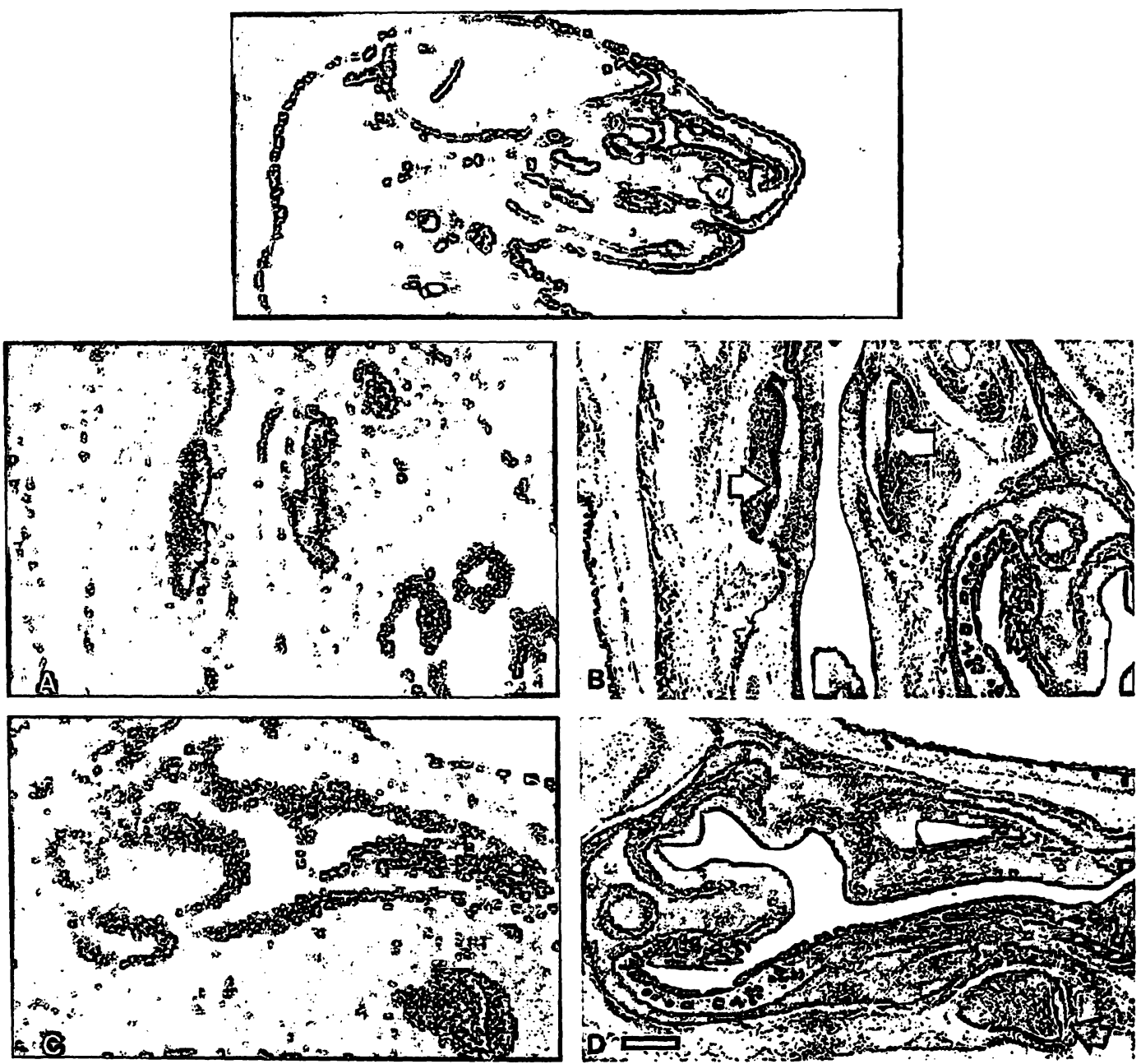

Fig. 5 Expression of murine tooth germs. Transcripts are found in several craniofacial structures including molar and incisor teeth. (A) Darkfield image of transcripts in the dental epithelium. (B) A corresponding brightfield section. Arrows indicate dental epithe-

lium. (C) Darkfield image with transcripts in the nasal epithelium, odontoblasts and dental papilla of the incisor tooth. (D) Brightfield image of (C). Arrow points to the ameloblast layer of the incisor tooth. 
genic sites, but also in kidney, adrenal, urinary bladder, developing heart and a number of basement membranes separating the epithelium from the underlying stroma $(11,13,23)$. Osteogenic protein-1 transcripts are present in a variety of tissues, suggesting local and/or systemic release, particularly in the development of kidney, limb bud, bone, tooth (fig. 5), heart and intestine (24).

These data together with the specific affinity of osteogenin and bone morphogenetic protein-2 for the type IV collagen of the basement membrane (25), underscore the potential critical role of the extracellular matrix in sequestering differentiation factors and in regulating their bioavailability.

\section{Involvement of Bone Morphogenetic Proteins in the Endochondral Bone Formation Cascade}

In vitro studies allowed us to explore the effects of bone morphogenetic proteins on both cartilage and bone cells. Osteogenin stimulated alkaline phosphatase activity and collagen synthesis in rat periosteal cells and calvarial osteoblasts (26). There was also an increase in the formation of alkaline phosphatase-positive colonies in rat bone marow stromal cell cultures (26). The promotion of the osteogenic phenotype was confirmed in experiments with MC3T3-E1 osteoblastic cells; Osteogenin inhibited growth and stimulated alkaline phosphatase activity within 72 hours (27), while usually about 12 days are needed for their spontaneous differentiation in vitro (28). In the same cells, high-affinity receptors for bone morphogenetic protein-2 have been identified (29). Several studies using either bone morphogenetic protein-2, 3 or 4 have confirmed and extended these original data on bone morphogenetic proteins promoting the osteoblastic phenotype $(30-32)$.

Chondrogenic activity of bone morphogenetic proteins

A profound stimulation of proteoglycan synthesis in fetal rat chondroblasts and rabbit articular chondrocytes (26), together with increased cartilage matrix synthesis in chick limb bud cell cultures $(33-34)$, demonstrated the role of osteogenin in the promotion of the chondrogenic phenotype. Osteogenin and bone morphogenetic protein-4 were equipotent in the maintenance of proteoglycan metabolism in articular cartilage explant cultures of young, adolescent and adult tissues by increasing proteoglycan synthesis and decreasing proteoglycan catabolism (35). Analysis of the newly synthesized proteoglycans, the glycosaminoglycan chain size, and the glycosaminoglycan type of explants treated with osteogenin or bone morphogenetic protein-4 indicated that they were very similar. Thus, both osteogenin and bone morphogenetic protein-4 alone are capable of stimulating and maintaining the chondrocyte phenotype in vitro (35). Taken together, these in vitro data suggest that bone morphogenetic proteins play a role not only in the initiation of cartilage and bone formation, but clearly promote the expression and maintenance of the chondrogenic and osteogenic phenotype. The potential role

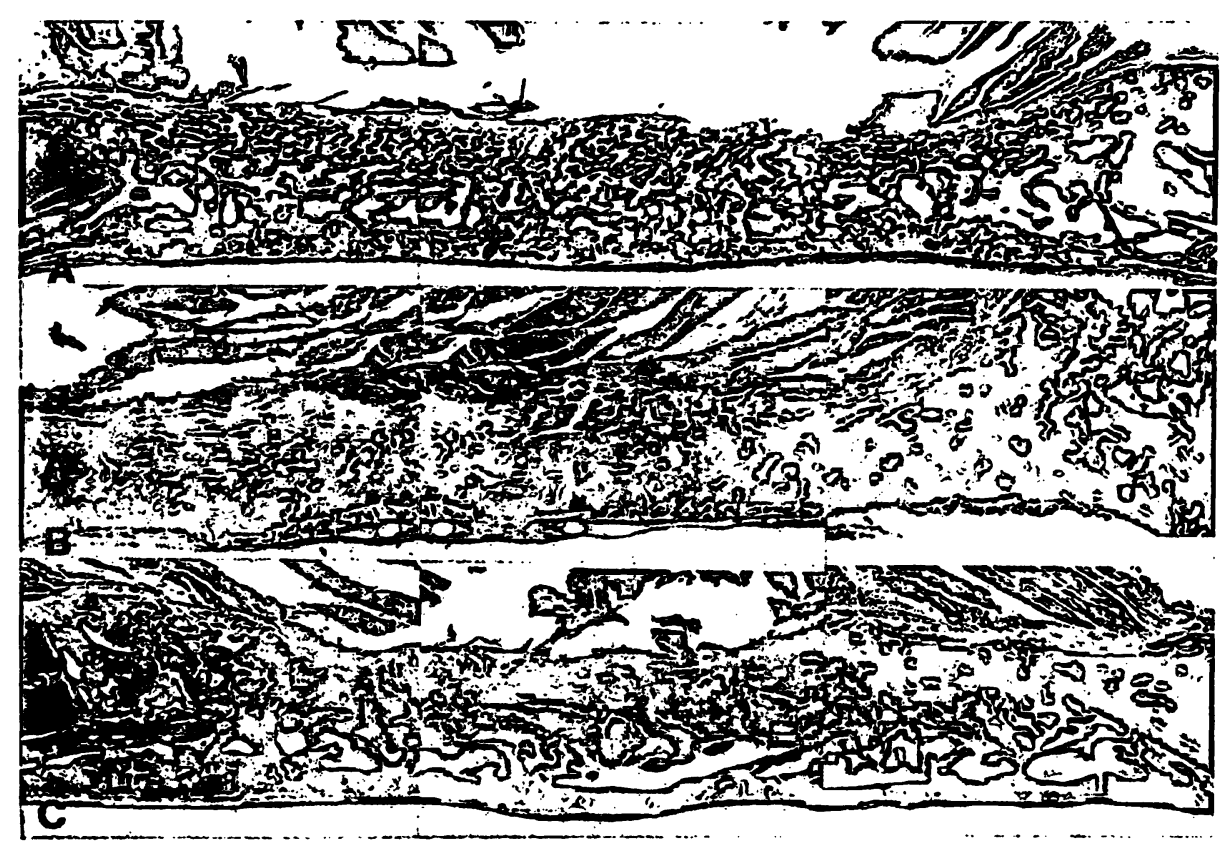

Fig. 6 Composite photomicrographs of sagittal sections of three baboon cranial defects A-C. Fulli-thickness circular cranial defects, $25 \mathrm{~mm}$ in diameter were trephined on the exposed calvariae and implanted with insoluble collagenous matrix reconstituted with baboon osteogenin (bone morphogenetic protein-3). Sections were cut from three specimens harvested from three different animals on day 90 after surgery. Extensive bone formation is present in all adult primates. (Reproduced from Ripamonti et al.; Plast Reconstr Surg 1993; 91:27) (43). 
of bone morphogenetic proteins in healing cartilage defects is described later. It was found that osteogenic protein-1 (BMP-7) promotes cell proliferation and chondrocyte maturation without requiring either thyroid hormone or insulin, agents known to support chondrocyte differentiation in vitro. By comparison, transforming growth factor $\beta$ and retinoic acid neither initiated nor promoted chondrocyte differentiation (36).

\section{Discovery and Potential Function of Cartilage- Derived Morphogenetic Proteins}

Partially purified extracts from newborn calf articular cartilage were found to induce cartilage and bone when implanted subcutaneously in rats. This activity showed characteristics reminiscent of bone morphogenetic proteins. Degenerated oligonucleotide primer sets derived from the highly conserved carboxy-terminal region of the bone morphogenetic protein family were designed and used in reverse transcription-polymerase chain reactions with poly(A) ${ }^{+}$RNA from articular cartilage as template to determine which bone morphogenetic proteins are produced by chondrocytes. Two novel members of the transforming growth factor- $\beta$ superfamily were identified and designated as cartilage-derived morphogenetic protein-1 and -2 . Their $\mathrm{C}$-terminal transforming growth factor- $\beta$ domains are $82 \%$ identical, thus defining a novel subfamily most closely related to bone morphogenetic protein-5, bone morphogenetic protein- 6 and osteogenic protein-1 (fig. 3b). Northern analyses showed that both genes are expressed predominantly in cartilaginous tissues. In situ hybridization and immunostaining showed that cartilage-derived morphogenetic protein-1 was found predominantly at the stage of precartilaginous mesenchymal condensation and throughout the cartilaginous cores of the developing long bones, whereas carti- lage-derived morphogenetic protein-2 expression was restricted to the hypertrophic chondrocytes of ossifying long bone centers (37). Neither gene was detectable in the axial skeleton during human embryonic development. The genetic map location for cartilage-derived morphogenetic protein-1 was defined on mouse chromosome 2 by Southern blot analysis of the progeny of two multilocus crosses. The cartilage-specific localization pattern of these novel transforming growth factor- $\beta$ superfamily members, which contrasts with the more ubiquitous presence of other bone morphogenetic protein family members, suggests a potential role for these proteins in chondrocyte differentiation and growth of long bones (37). Moreover, recombinantly expressed cartilage-derived morphogenetic protein-1 induced cartilage at ectopic sites in rats (tab. 1). Several recombinantly expressed bone morphogenetic proteins can induce bone at ectopic sites in vivo (tab. 1). This apparent redundancy has gained much attention and recently it has been demonstrated that, apart from inducing bone development and regeneration, different bone morphogenetic proteins are the key mediators in initiating the development of parenchymatous organs; e.g. bone morphogenetic protein- 4 mediation of tooth development (38) and osteogenic protein-1 initiation of kidney mesenchyme induction (Vukičević et al., in preparation).

\section{Potential Therapeutic Application of Bone Differentiation Factors}

The availability of bone morphogenetic proteins has made it possible to extend the knowledge of their in vivo morphogenic potential in rodents to primates, a prerequisite for the exploration of potential therapeutic applications for the regeneration of bone in man.

Tab. 2 Skeletal localization and the type of bone morphogenetic protein preparation used for craniofacial regeneration

\begin{tabular}{ll}
\hline Skeletal localization and species & Authors \\
\hline $\begin{array}{l}\text { 1. Regeneration of calvaria in dogs (bovine bone morphogenetic protein) } \\
\begin{array}{l}\text { 2. Bone morphogenetic protein and } \beta \text {-tricalcium phosphate composite in skull trephine defects } \\
\text { in dogs (bovine bone morphogenetic protein) }\end{array}\end{array}$ & Sato K, Urist MR. 1985 (39) \\
$\begin{array}{l}\text { 3. Repair of craniotomy defects in rhesus monkey (bovine bone morphogenetic protein) } \\
\text { 4. Calvarial reconstruction in baboons (recombinant human bone morphogenetic protein) }\end{array}$ & Ferguson D et al. 1987 (41) \\
$\begin{array}{l}\text { 5. Mandibular reconstruction in dogs (recombinant human bone morphogenetic protein) } \\
\text { 6. Regeneration of attachment apparatus of the human teeth (human bone morphogenetic } \\
\text { protein) }\end{array}$ & $\begin{array}{l}\text { Ripamonti U. 1991 (42), al. 1992 (43) } \\
\text { 7. Repair of rat craniotomy defects (bovine bone morphogenetic protein) }\end{array}$ \\
\hline
\end{tabular}




\section{Craniofacial applications}

Table 2 shows the skeletal localization and the type of bone morphogenetic protein preparation used for experiments on the craniofacial skeleton.

First experiments on craniofacial regeneration were carried out using bovine native bone morphogenetic protein. Bone regeneration under the influence of a bone morphogenetic protein $\beta$-tricalcium phosphate composite in skull trephine defects in dogs was investigated by Urist et al. (39). $\beta$-Tricalcium phosphate was employed as a non-immunogenic biodegradable delivery system for bovine bone morphogenetic protein. Bone morphogenetic protein/ $\beta$-tricalcium phosphate implants induced $91-100 \%$ of new bone deposits $(39,40)$. Ferguson et al. (41) proved that purified bovine bone morphogenetic protein induces repair of craniotomy defects. The morphogenetic responses included mesenchymal cell proliferation, chondrogenesis, and increased bone formation.

The healing potential of osteogenin on calvarial defects in a series of adult primates of genus Papio (baboon) has been studied. In 48 adult male baboons, calvarial defects were implanted with graft of autogenous bone harvested from the iliac crest, and with different osteoconductive and osteoinductive substrates (42). Reconstitution of calvarial defects with baboon osteogenin induced huge amounts of new bone as early as 30 days. At 3 months, bone formation was extensive, culminating in complete regeneration of the craniotomy defects (43-46). A single application of human recombinant transforming growth factor- $\beta 1$ in a $3 \%$ methylcellulose gel to skull defects in New Zealand white rabbits induced a dose dependent increase in intramembranous bone formation (47). Complete bony bridging of defects occurred within 28 days after treatment with $2 \mu \mathrm{g}$ of transforming growth factor- $\beta 1$. Transforming growth factor- $\beta 1$ in contrast is not osteogenic when implanted with a carrier at orthotopic sites $(7,8,48)$.

Bone morphogenetic proteins were recently tested for their regenerating effects in human periodontal intrabony defects $(49,50)$. Combined with insoluble collagenous bone matrix, bone morphogenetic proteins induced regeneration of cementum, periodontal ligament and alveolar bone in furcation defects created in adult baboons (50). Periodontal regeneration is one of the major goals of periodontal therapy. The use of recombinant human bone morphogenetic proteins is in the experimental phase, but shows promise of increasing the regeneration of enamel and periodontal ligament and augmentation of mandibles $(49,50)$.

\section{Orthopaedic applications}

Two preliminary reports on the treatment of large bony defects in human lower limbs by implants containing native human bone morphogenetic protein have been published. In the first, 12 patients with established nonunion of the femoral diaphysis junction received autogenous grafts or allografts with the preparation of purified bone morphogenetic protein (51). Union was obtained in 11 of 12 cases at an average time of 4.7 months after grafting. The second report described 6 patients with segmental tibial defects, 3 to $17 \mathrm{~cm}$ long, who obtained solid bony union after implantation of bone morphogenetic protein and autogenous bone grafts (52). The osteogenic effect of bone morphogenetic protein in such

Tab. 3 Experimental and clinical orthopaedic applications of bone morphogenetic proteins

$\begin{array}{ll}\text { Dkeletal localization and species Authors } & \text { A }\end{array}$

1. Grafting of resistant femoral non-unions (purified bone morphogenetic proteins)

2. Cancellous bone grafts augmented with purified bone morphogenetic protein in repair of segmental defects of the tibia

3. Purified bone morphogenetic protein and insoluble non-collagenous proteins in extensive $(3-4 \mathrm{~cm})$ segmental ulnar defects in dogs

4. Healing of segmental bone defects (in femurs of adult male rats) recombinant human bone morphogenetic protein-2

5. Healing of large mid-part defects of the ulnar shaft of adult rabbits; recombinant human osteogenic protein-1

6. Ulnar or tibial diaphyseal segmental defects in rabbits, dogs and primaes; recombinant human osteogenic protein-1

7. Rats and rabbits osseous defects; recombinant human bone morphogenetic protein-2

8. Canine and rabbit spinal fusion model (recombinant human bone morphogenetic protein-2 and recombinant human osteogenic protein-1)
Johnson EE, Urist MR et al. $1988(51-52)$

Johnson EE, Urist MR et al. 1989 (81)

Johnson EE, Urist MR et al. 1989 (81)

Yasko WA et al. 1992 (53)

Cook DS et al. 1994 (54)

Rueger DC, Tucker MM, Cook SD 1994 (55)

Lane JM, Yasko A et al. 1994 (56)

Musher FG et al. 1994 (57), Cook DS et al. 1994 (58), Boden SD et al. 1994 (59).

Sandhy $H S$ et al. 1994 (60), Yasko (53) 
complex procedures was difficult to estimate. Nevertheless, the results were encouraging, since most of the patients had previously undergone several unsuccessful operations (tab. 3). Recently, several investigations using bone morphogenetic proteins obtained by recombinant technology have been concluded confirming positive results in bone regeneration achieved with native bone morphogenetic protein preparations. Yasko et al. (52) investigated the healing of segmental femoral defects in rats induced by recombinant human bone morphogenetic protein-2. Two doses $(1.4$ or $11.0 \mu \mathrm{g}$ ) of lyophilised recombinant human bone morphogenetic protein- 2 were implanted in each defect, together with guanidine-hydrochloride extracted demineralized rat-bone matrix as a carrier. Implantation of $11.0 \mu \mathrm{g}$ of recombinant human bone morphogenetic protein-2 resulted in significant bone formation, as shown by radiographic, histological and mechanical evidence of union.'

Cook et al. (54) investigated the effect of recombinant human osteogenic protein-1 (BMP-7) on healing of large segmental ulnar defects in rabbits. The implants consisted of a collagen carrier $(125 \mathrm{mg})$ of demineralized guanidine-extracted, insoluble rabbit bone matrix, recon-

Tab. 4 Various organic and inorganic materials used as bone morphogenetic protein carriers or delivery systems

\begin{tabular}{ll}
\hline Carrier substrate or delivery system & Authors
\end{tabular}

1. B-Tricalcium phosphate

2. Autogenic cancellous bone graft combined with an onlay of purified bone morphogenetic protein/non-collagenous proteins

3. Purified bone morphogenetic protein/non-collagenous proteins suspended in a strip $(1 \times 13 \mathrm{~cm})$ of polylactic/polyglycolic acid copolymer or in gelation capsules

4. Bone matrix non-collagenous proteins

5. Porous hydroxyapatite combined with collagen

6. Composite of bone morphogenetic protein and plaster of paris

7. Demineralized bone matrix and bone morphogenetic protein in clot of blood

8. Telopeptide-depleted bovine skin collagen

9. Polylactic acid homopolymers

10. Porous hydroxyapatite (replicas) obtained after hydrothermal conversion of calcium carbonate exoskeleton of corals

11. Type I collagen

12. Porous hydroxyapatite blocks in form of discs ( $7 \mathrm{~mm} \emptyset, 3 \mathrm{~mm}$ thick) or granules $(400-620 \mu \mathrm{m} \varnothing)$

13. Millipore diffusion chambers

14. Polylactic acid-polyethylene glycol block copolymer

15. Spongy titanium formed into a rice-shaped particle $\left(2 \mathrm{~mm}^{3}\right)$

16. Natural coral skeleton in granules + fibrinogen glue

17. Porous biodegradable copolymer, poly $(D, L, \mathrm{C}$ (lactide-coglycide)) particles (diameter $100-700 \mu \mathrm{m}$ )

18. Poly $\alpha$-hydroxyacids as delivery vehicle

19. Fibrous glass membrane (fiber $1 \mu \mathrm{m}$, thickness $0.6 \mathrm{~mm}$ ) or porous particles of hydroxyapatite

20. Granulated hydroxyapatite and fibrin

21. Chilin complex (artificial skin, absorbable thread)

22. Fibrous collagen membrane No. 3 from telopeptide,depleted bovine skin collagen

23. Microcapsules made as mixture of poly $D, L$-lactide-co-glycolide and polyethylene glycol methyl ether
Urist $M R$ et al. 1984 (61)

Johnson EE, Urist MR et al. 1988 (51)

Johnson EE, Urist MR et al. 1988 (52)

Kawamura M, Urist MR et al. 1988 (62)

Takaoka $K$ et al. 1988 (63)

Yamazaki $Y$ et al. 1988 (64)

Toriumi DM et al. 1991 (79)

Takaoka K, Kozeuka M, Nakahara H 1991 (65)

Miyamoto $S$ et al. 1992 (66)

Ripamonti U, Ma S, Reddi AH 1992 (67)

Fujimari $Y$ et al. 1992 (68)

Ripamonti U, Ma S, Reddi AH 1992 (67)

Miyamoto S, Takaoka K, Ono K 1993 (69)

Miyamoto $S$ et al. 1993 (70)

Kawai $T$ et al. 1993 (71)

Arnoud E, Vernejoul MC 1994 (72)

Muschler GF et al. 1994 (57)

Hollinger $J 1994$ (73)

Kuboki $Y$ et al. 1994 (74)

Sato $T 1994$ (75)

Miyazava K et al. 1994 (76)

Kawanami $M$ et al. 1994 (77)

Isobe $M$ et al. 1994 (78) 
stituted with $3.13,6.25,12.5,25.0,50.0,100,200,300$ or $400 \mu \mathrm{g}$ of recombinant human osteogenic protein-1. All implants, except for those containing only $3.13 \mu \mathrm{g}$ of substance, induced complete radiographic osseus union within eight weeks. Histological evaluation of this new bone revealed primarily lamellar bone, with the formation of new cortices and normal-appearing marrow elements. Moreover, a single local application of recombinant human osteogenic protein-1 on a carrier material can completely restore large orthopaedic defects (55).

The possibility of using bone morphogenetic proteins in spinal fusion has been carefully explored. The efficacy of recombinant human bone morphogenetic protein-2 delivered in a porous biodegradable copolymer, poly( $D, L$-lactide-coglycide) was evaluated using a canine posterior segmental spinal fusion model $(56,57)$. Union score and mechanical testing showed no difference between autogenous cancellous bone and recombinant human bone morphogenetic protein-2. These findings suggest that synthetic bone graft substitutes delivering recombinant human bone morphogenetic protein- 2 may be suitable for posterior spinal fusions. The results obtained on a similar model by Cook et al. (58) indicated that recombinant human osteogenic protein-1 is an effective bone graft substitute for achieving stable posterior spinal fusion in a significantly more rapid fashion than can be achieved with autogenous bone graft. The results reported by Boden (59) and those of Sandhy et al. (60) confirmed that bone morphogenetic proteins may serve as powerful bone graft substitutes for lumbar spine fusion.

The possibility of using bone morphogenetic protein for the enhancement of osseous growth during implantation of cementless endoprothesis of hip and knee joints has also been the subject of preliminary clinical investigations. Bone morphogenetic proteins have proven both their osteoinductive and osteoconductive potentials as well as exceptional tolerance and immunological inertness. At present, clinical trials on human patients are being conducted. At this point in time, the greatest problem is the unresolved question of the carrier substance and delivery system.

\section{The carrier for bone morphogenetic proteins}

Carrier substrates will have to meet the following requirements:

1) relative insolubility in physiological conditions;

2) biodegradability;

3) protection against proteolytic activities;

4) function as substrate for cell adhesion and proliferation;

5) be immunologically inert;

6) achieve a slow release of a bone morphogenetic protein through controlled biological degradation, and

7) have mechanical stability in rebridging bony defects.

Some of these qualities are in part fulfilled by the various organic and inorganic materials which have been used as bone morphogenetic protein carriers (tab. 4) but this problem has not yet been completely solved by any research group. The fulfilment of the ideal properties of an osteoinductive material, based on synthetic or natural carrier, is a promising challenge for biomaterial research.

Definitive evaluation of the clinical use of bone morphogenetic protein will be possible after all the different factors influencing implant activity have been elucidated, and after development of an appropriate carrier.

\section{References}

1. Huggins $\mathrm{CB}$. The formation of bone under the influence of epithelium of the urinary tract. Arch Surg 1931; 22:377-408.

2. Urist MR. Bone: formation by autoinduction. Science 1965; 150:893-9.

3. Reddi $\mathrm{AH}$, Huggins $\mathrm{CB}$. Biochemical sequences in the transformation of normal fibroblasts in adolescent rats. Proc Natl Sci USA 1972; 69:1601 -5.

4. Reddi AH. Cell biology and biochemistry of endochondral bone development. Collagen Rel Res 1981; 1:209-26.

5. Sampath TK, Reddi AH. Dissociative extraction and reconstitution of extracellular matrix components involved in local bone differentiation. Proc Natl Acad Sci USA 1981; 78:7599-602.

6. Sampath TK, Reddi AH. Homology of bone-inductive proteins from human, monkey, bovine and rat extracellular matrix. Proc Natl Acad Sci USA 1983; 80:6591-5.

7. Sampath TK, Muthukumaran N, Reddi AH. Isolation of osteogenin, an extracellular matrix-associated bone inductive protein, by heparin affinity chromatography. Proc Natl Acad Sci USA 1987; 84:71.09-13.

8. Luyten FP, Cunningham NS, Ma S, Muthukumaran RG, Hammonds RG Jr, et al. Purification and partial amino acid sequence of osteogenin, a protein initiating bone differentiation. J Biol Chem 1989; 264:13777-80.

9. Wozney JM, Rosen V, Caleste AJ, Mitsock LM, Whitters RW, Kriz RW, et al. Novel regulators of bone formation: molecular clones and activities. Science 1988; 242:1528-34.

10. Celeste AJ, Ianazzi JA, Taylor RC, Hewock RM, Rosen V, et al. Identification of transforming growth factor $\beta$ family members present in bone inductive protein purified from bovine bone. Proc Natl Acad Sci USA 1990; 87:9843-7.

11. Ozkaynak E, Rueger DC, Drier EA, Corbett C, Ridge RJ, Sampath TK, et al. Op-1 cDNA encodes an osteogenic protein in TGF- $\beta$ family. EMBO J 1990; 9:2085-93.

12. Hammonds RG, Schwall R, Dudley A, Berkmeier L, Lai C, Lee $\mathrm{J}$, et al. Bone inducing activity of mature BMP-2b produced from hybrid BMP-2a/2b precursor. Mol Endocrinol 1991; 5:149-55.

13. Ozkaynak E, Schnegelsberg PNJ, Jin DF, Clifford GM, Warren FG, Drier EA, et al. Osteogenic protein-2. A new nember of 
the transforming growth factor- $\beta$ superfamily expressed early in embryogenesis. J Biol Chem 1992; 267:25220-7.

14. Wang EA, Rosen V, Cordes P, Hewick RM, Kriz MJ, Luxenburg DP, et al. Recombinant human bone morphogenetic protein induces bone formation. Proc Natl Acad Sci USA 1990; 87:2220-4.

15. Ferguson EL, Anderson KV. The decapentaplegic acts as a morphogen to organize dorso-ventral pattern in the drosophila embryo. Cell 1992; 71:451-61.

16. Massague $J$. The transforming growth factor- $\beta$ family. Annu Rev Cell Biol 1990; 6:597-641.

17. Sampath TK, Coughlin JE, Whetstone RM, Banach D, Corbett $\mathrm{C}$, Ridge RJ, et al. Bovine osteogenic protein is composed of dimers of OP-1 and BMP-2a. Two members of the transforming growth factor- $\beta$ superfamily. J Biol Chem 1990; 265:13198-205

18. Jones CM, Lyons KM, Hogan BLM. Involvement of bone morphogenetic protein-4 (BMP-4) and Vgr-1 in morphogenesis and neurogenesis in the mouse. Development 1991; 111:531-42.

19. Lyons K, Graycar JL, Lee A. Hashimi S, Lindquist PB, Chen EY, et al. Vgr-1, a mammalian gene related to Xenopus Vg-1, is a member of the transforming growth factor $\beta$ gene superfamily. Proc Natl Acad Sci USA 1989; 86:4554-8.

20. Lyons KM, Pelton RW, Hogan BLM. Organogenesis and pattern formation in the mouse: RNA distribution patterns suggest a role for bone morphogenetic protein-2A (BMP-2A). Development 1990; 109:833-44.

21. Ozkaynak E, Schnegelsberg PNJ, Oppermann H. Murine osteogenic protein (OP-1): high levels of mRNA in kidney. Biochem Biophys Res Commun 1991; 179:116-23.

22. Vukičević S, Paralkar VM, Cunningham NS, Gutkind JS, Reddi AH. Autoradiographic localization of osteogenin binding sites in cartilage and bone during embryonic development. Dev Biol 1990; 140:209-14.

23. Vukičević S, Latin V, Chen P, Batorsky R, Reddi AH, Sampath TK. Localization of OP-1 during embryonic development: high affinity binding to basement membranes. Biochem Biophys Res Commun 1994; 198:693-700.

24. Helder MN, Ozkaynak E, Sampath TK, Luyten FP, Latin V, Opperman H, Vukičević S. Expression pattern of osteogenic protein-1 (bone morphogenetic protein-7) in human and mouse development. J Histochem Cytochem 1995. In press.

25. Paralkar VM, Nandedkar AKN, Pointer RH, Kleinman HK, Reddi AH. Interaction of osteogenin, a heparin binding bone morphogenetic protein, with type IV collagen. J Biol Chem 1990; 265:281-4

26. Vukičević S, Luyten F, Reddi AH. Stimulation of the expression of osteogenic and chondrogenic phenotypes in vitro by osteogenin. Proc Natl Acad Sci USA 1989; 86:8793-7.

27. Vukičević S, Luyten F, Reddi AH. Osteogenin inhibits proliferation and stimulates differentiation in mouse osteoblast-like cells (MC3T3-E1). Biochem Biophys Res Commun 1990: 166:7506.

28. Kodama H, Amagai Y, Dudo H, Kasai S, Yamamoto S. Establishment of a clonal osteogenic cell line from newborn mouse calvaria. Jpn J Oral Biol 1981; 23:899-901.

29. Chen P, Carrington JL, Hammonds RG, Reddi AH. Stimulation of chondrogenesis in limb bud mesoderm cells by recombinant human bone morphogenetic protein 2B (BMP-2B) and modulation by transforming growth factor 1 and 2. Exp Cell Res 1991; 195:509-15.

30. Hiraki $Y$, Inoue $H$, Shigeno $C$, Sanma $Y$, Bentz $H$, Rosen DM, et al. Bone morphogenetic proteins (BMP-2 and BMP-3) promote growth and expression of the differentiated phenotype of rabbit chondrocytes and osteoblastic MC3T3-E1 cells in vitro. J Bone Miner Res 1991; 6:1373-85.

31. Takuwa Y, Ohse C, Wang EA, Wozney JM, Yamashita K. Bone morphogenetic protein-2 stimulates alkaline phosphatase activity and collagen synthesis in cultured osteoblastic cells, MC3T3-E1. Biochem Biophys Res Commun 1991; 174:1349-52.
32. Yamaguchi A, Katagiri T, Ikeda T, Wozney JM, Rosen V, Wang EA, et al. Recombinant human bone morphogenetic protein-2 stimulates osteoblastic maturation and inhibits myogenic differentiation in vitro. J Cell Biol 1991; 113:681-7.

33. Carrington JL, Chen P, Yanagishita M, Reddi AH. Osteogenin (bone morphogenetic protein-3) stimulates cartilage formation by chick limb bud cells in vitro. Dev Biol 1991; 146:406-15.

34. Chen TL, Bates RL, Dudley A, Hammonds RG Jr, Amento EP. Bone morphogenetic protein-2b stimulation of growth and osteogenic phenotypes in rat osteoblast-like cells: comparison with TGF- $\beta 1$. J Bone Miner Res 1991; 6:1387-93.

35. Luyten FP, Yu YM, Yanagishita M, Vukičević S, Hammonds RG, Reddi AH. Natural bovine osteogenin and recombinant human bone morphogenetic protein-2B are equipotent in the maintenance of proteoglycans in bovine articular cartilage explant cultures. J Biol Chem 1992; 267:3691-5.

36. Chen P, Vukičević S, Sampath TK, Luyten FP. Osteogenic protein-1 promotes growth and maturation of chick sternal chondrocytes in serum-free cultures. J Cell Sci 1995; 108:105-14.

37. Chang SC, Hoang B, Thomas JT, Vukičević S, Luyten FP, Ryba NJP, et al. Cartilage derived morphogenetic proteins. New members of the transforming growth factor $\beta$ superfamily predominantly expressed in long bones during human embryonic development. J Biol Chem 1994; 269:28227-34.

38. Vainio S, Karavanova I, Jowett A, Thesleff I. Identification of BMP-4 as a signal mediating secondary induction between epithelia and mesenchyme tissues during early tooth development. Cell 1993; 75:45-58.

39. Sato K, Urist MR. Induced regeneration of calvaria by bone morphogenetic protein (BMP) in dogs. Clin Orthop 1985; 197:30111.

40. Urist MR, Nilsson $O$, Rasmussen J, Hirota $W$, Lovell $T$, Schmalzreid $\mathrm{T}$, et al. Bone regulation under the influence of a bone morphogenetic protein (BMP) $\beta$ Tricalcium Phosphate (TCP) composite in skull trephine defects in dogs. Clin Orthop 1987; 214:295-304.

41. Ferguson D, Davis WL, Urist MR, Hurt WC, Allen EP. Bovine Bone Morphogenetic Protein (bBMP) fraction-induced repair of craniotomy defects in the Rhesus Monkey (Macaca speciosa). Clin Orthop 1987; 219:251-8.

42. Ripamonti U. Bone induction in nonhuman primates. Clin Orthop $1991 ; 269: 284-94$.

43. Ripamonti U, Ma SS, Cunningham NS, Yeates L, Reddi AH. Reconstruction of the bone - bone marrow organ by osteogenin, a bone morphogenetic protein, and demineralized bone matrix in calvarial defects of adult primates. Plast Reconstr Surg 1993; 91:27-36.

44. Ripamonti U, Ma SS, Cunningham NS, Yeates L, Reddi AH. Initiation of bone regeneration in adult baboons by osteogenin, a bone morphogenetic protein. Matrix 1992; 12:369-80.

45. Ripamonti U, Reddi AH. Growth and morphogenetic factors in bone induction: role of osteogenin and related bone morphogenetic proteins in craniofacial and periodontal bone repair. Crit Rev Oral Biol Med 1992; 3:1-14.

46. Ripamonti U, Ma S, van den Heever B, Reddi AH. Osteogenin a bone morphogenetic protein, adsorbed on porous hydroxyapatite substrata induces rapid bone differentiation in calvarial defects in adult primates. Plast Reconstr Surg 1992; 90:38293.

47. Beck LS, Deguzman L, Lee WP, Xu Y, McFatridge LA, Gillett NA, et al. TGF- $\beta 1$ induces bone closure of skull defects. J Bone Mineral Res 1991; 6(11):1257-65.

48. Bašić N, Bašić $V$, Bulić $K$, Grgić $M$, Kleinman HK, Luyten FP, et al. TGF- $\beta$ from basement membranes stimulates the chondrogenic phenotype in osteoblastic cells derived from fetal rat calvaria. J Bone Mineral Res 1995. In press.

49. Ripamonti U, Reddi AH. Periodontal regeneration: potential role of bone morphogenetic proteins. J Periodont Res 1994; 29:225-35.

50. Ripamonti U, Heliotis M, Van Der Heever B, Reddi AH. Bone morphogenetic proteins induce periodontal regeneration in the baboon (Papio Ursinus). J Periodónt Res 1994; 29:439-45. 
51. Johnson EE, Urist MR, Finerman GAM. Bone morphogenetic protein augmentation grafting of resistant femoral nonunions. Cell Orthop 1988; 230:257-65.

52. Johnson EE, Urist MR, Finerman GAM. Repair of segmental defects of the tibia with cancellous bone grafts augmented with human bone morphogenetic protein. Clin Orthop 1988; 236:249-57.

53. Yasko AW, Lane JM, Fellinger EJ, Rosen V, Wozney JM, Wang EA. The healing of segmental bone defects, induced by recombinant human bone morphogenetic protein (rhBMP-2). J Bone Joint Surg 1992; 74A:659-70.

54. Cook SD, Baffes GC, Wolfe MW, Sampath TK, Rueger DC, Whitecloud TS. The effect of recombinant human osteogenic protein-1 on healing of large segmental bone defects. J Bone Joint Surg 1994; 76A:827-37.

55. Rueger DC, Tucker MM, Cook SD. Preclinical studies evaluating the use of recombinant osteogenic protein-1 in the repair and regenerating of orthopaedic defects. Proceedings of the International Conference on Bone Morphogenetic Proteins 1; 1994; Baltimore, Maryland.

56. Lane JM, Yasko A, Tomin E, Bostrom M, Rosen V, Wozney $\mathrm{J}$. Orthopaedic application of BMP-2 in fracture healing. Proceedings of the International Conference on Bone Morphogenetic Proteins 1; 1994; Baltimore, Maryland.

57. Muschler GF, Hyodo A, Manning T, Kambic H, Easley K. Evaluation of human bone morphogenetic protein 2 in a canine spinal fusion model. Clin Orthop 1994; 308:229-40.

58. Cook SD, Dalton JE, Tan EH, Whitecloud TS, Rueger DC. In vivo evaluation of recombinant human osteogenic protein (rhOP-1) implants as a bone graft substitute for spinal fusions. Spine 1994; 19(15):1655-63.

59. Boden SD, Schimandle JH, Wozney J. Use of bone morphogenetic protein to achieve spinal fusion. Proceedings of the International Conference on Bone Morphogenetic Proteins 1; 1994; Baltimore, Maryland.

60. Sandhy HS, Kanim LEA, Kabo JM, Zeegen EN, Liu D, Seeger LL, et al. Evaluation of rh-BMP with an OPLA carrier in a canine posterolateral (transverse process) spinal fusion model. Proceedings of the International Conference on Bone Morphogenetic Proteins 1; 1994; Baltimore, Maryland.

61. Urist MR, Lietze A, Dawson E. $\beta$-tricalcium phosphate delivery system for bone morphogenetic protein. Clin Orthop 1984; 187:277-80.

62. Kawamura $M$, Urist MR. Induction of callus formation by implants of bone morphogenetic protein and associated bone matrix noncollagenous proteins. Clin Orthop 1988; 236:240-8.

63. Takaoka $K$, Nakahara $H$, Yoshikawa $H$, Masuhara $K$, Tsuda $T$, Ono $\mathrm{K}$. Ectopic bone induction on and in porous hydroxyapatite combined with collagen and bone morphogenetic protein. Clin Orthop 1988; 234:250-4.

64. Yamazaki Y, Oida S, Akimoto Y, Shioda S. Response of the mouse femoral muscle to an implant of a composite of Bone Morphogenetic Protein and Plaster of Paris. Clin Orthop 1988; 234:240-9.

65. Takaoka K, Koezuka M, Nakahara H. Telopeptide-depleted bovine skin collagen as a carrier for bone morphogenetic protein. J Orthop Res $1991 ; 9(6): 902-7$

66. Miyamoto S, Takaoka K, Okada T, Yoshikawa H, Hashimoto J, Suzuki S, et al. Evaluation of polylactic acid homopolymers as carriers for bone morphogenetic protein. Clin Orthop 1992; 278:274-85.

67. Ripamonti U, Ma S, Reddi AH. The critical role of geometry of porous hydroxyapatite delivery system in induction of bone by osteogenin, a bone morphogenetic protein. Matrix 1992; $12: 202-12$.

68. Fujimori Y, Nakamura T, Ijiri S, Shimizu K, Yamamuro T. Heterotopic bone formation induced by bone morphogenetic pro- tein in mice with collagen-induced arthritis. Biochem Biophys Res Comm 1992; 186(3):1362-7.

69. Miyamoto S, Takaoka K, Ono K. Bone induction in monkeys by bone morphogenetic protein. J Bone Joint Surg 1993; 75b:107-10.

70. Miyamoto S, Takaoka K, Okada T, Yoshikawa $\mathrm{H}$, Hashimoto J, Suzuki S, et al. Polylactic acid-polyethylene glycol block copolymer. Clin Orthop 1993; 294:333-43.

71. Kawai T, Mieki A, Ohno Y, Umemura M, Kataoka H, Kurita $S$, et al. Osteoinductive activity of composites of bone morphogenetic protein and pure titanium. Clin Orthop 1993; 290:296-305.

72. Arnaud E, Vernejoul MC. Potentiation of bone growth factor by coral and fibrinogen. Proceedings of the International Conference on Bone Morphogenetic Proteins 1; 1994; Baltimore, Maryland.

73. Hollinger J. Poly alfa-hydroxyacids as delivery vehicle for bone repair. Proceedings of the International Conference on Bone Morphogenetic Proteins 1; 1994; Baltimore, Maryland.

74. Kuboki $Y$, Saito $T$, Murata $M$, Takita $H$, Mizuno $M$, Inque $M$, et al. Geometrical factors of matrix for cell-differentiation: effects of various cell substrata on the BMP-induced chondroand osteogenesis. Proceedings of the International Conference of Bone Morphogenetic Proteins 1; 1994; Baltimore, Maryland.

75. Sato T, Kawamura M, Sato K, Iwata $H$. Bone formation of rabbit bone morphogenetic protein bound hydroxyapatite and fibrin composite. Proceedings of the International Conference on Bone Morphogenetic Proteins 1; 1994; Baltimore, Maryland.

76. Miyazava K, Kawai T, Kato N, Ika M, Nagao T, Kataoka Y, et al. Osteoinductive activity of BMP-Chilin complex. Proceedings of the International Conference on Bone Morphogenetic Proteins 1; 1994; Baltimore, Maryland.

77. Kawanami M, Matsumoto A, Ito Y, Saito A, Kato H, Kuboki Y. A histological study of bone induction by bone morphogenetic protein combined with fibrous collagen membrane in artificial alveolar bone defects in adult rats. Proceedings of the International Conference on Bone Morphogenetic Proteins 1; 1994; Baltimore, Maryland.

78. Isobe $M$, Yamazaki $Y$, Ishihara $K$, Nukabayashi $N$, Amagasa $T$. Investigation of relationship between characteristics of microcapsules containing bone morphogenetic protein (BMP) and osteoinductive activity. Proceedings of the International Conference on Bone Morphogenetic Proteins 1; 1994; Baltimore, Maryland.

79. Toriumi DM, Kotler HS, Luxenberg DP, Holtrop ME, Wang EA. Mandibular reconstruction with a recombinant bone-inducing factor. Arch Otolaryngol Head Neck Surg 1991; 117:1101-12.

80. Bowers G, Felton F, Middleton C, Glynn D, Sharp S, Melionig $\mathrm{J}$, et al. Histologic comparison of regeneration in human intrabony defects when osteogenin is combined with demineralized freeze-dried bone allograft and with purified bovine collagen. J Periodontol 1991; 62(11):690-702.

81. Johnson EE, Urist MR, Schmalzried TP, Chotivichit A, Huang HK, Finerman GAM. Autogenic cancellous bone grafts in extensive segmental ulnar defects in dogs. Clin Orthop 1989; 243:254-65.

Prof. Dr. Slobodan Vukičević

Department of Anatomy

School of Medicine

University of Zagreb

Šalata 11

10000 Zagreb

Croatia 
